\section{DIGITAL COMMONS \\ @ UNIVERSITY OF SOUTH FLORIDA}

\section{ABO: Interactive Journal for Women in the Arts, 1640-1830}

Volume 2

Issue 2 Volume 2.2 (Fall 2012): Open Access

Article 8

2012

\title{
Funding, Grants, Hiring, Programs: Sharing Advice on How to get Things Done in Hard Times
}

\author{
Srividhya Swaminathan \\ Long Island University, Srividhya.Swaminathan@liu.edu
}

Follow this and additional works at: https://digitalcommons.usf.edu/abo

Part of the Dramatic Literature, Criticism and Theory Commons, Educational Methods Commons, Feminist, Gender, and Sexuality Studies Commons, and the Literature in English, British Isles Commons

\section{Recommended Citation}

Swaminathan, Srividhya (2012) "Funding, Grants, Hiring, Programs: Sharing Advice on How to get Things Done in Hard Times," ABO: Interactive Journal for Women in the Arts, 1640-1830: Vol.2: Iss.2, Article 8. http://dx.doi.org/10.5038/2157-7129.2.2.8

Available at: https://digitalcommons.usf.edu/abo/vol2/iss2/8

This Scholarship is brought to you for free and open access by Digital Commons @ University of South Florida. It has been accepted for inclusion in ABO: Interactive Journal for Women in the Arts, 1640-1830 by an authorized administrator of Digital Commons @ University of South Florida. For more information, please contact digitalcommons@usf.edu. 


\section{Funding, Grants, Hiring, Programs: Sharing Advice on How to get Things Done in}

Hard Times

\section{Keywords}

funding, research, seminar, state of the profession, teaching, travel

\section{Creative Commons License}

(c) $($ ) $\ominus$

This work is licensed under a Creative Commons Attribution-No Derivative Works 3.0 License. 
The current state of the academy does not favor the humanities with regards to funding. We have a limited number of lucrative fellowships to pursue and our grant opportunities border on nonexistent. A probable reason for the limited grant funding relates directly to the nature of research in the humanities. Most of our work is solitary and isolated, unlike other disciplines that publish collaboratively. As academics, many of us are focused too narrowly on a single path of success that leads from research to book or article to publication. Many of us treat our jobs as though we are seeking to achieve tenure at a top-level research university. However, for most scholars in the humanities, this is simply not the case. Increasingly, the jobs most commonly held are at smaller colleges and universities that classify themselves as teaching institutions. We also have a growing number of colleagues who are working as adjuncts. Therefore, when we think in terms of research leave, funding, and scholarly advancement, we need to consider other opportunities that are tailored to the humanities field. By this, I mean going back to the classroom as student rather than teacher and learning how to build different kinds of academic communities.

A number of institutions offer summer study options that can be an invaluable resource for learning new material and connecting with scholars from across the country. The three institutions with which I am most familiar are the National Endowment for the Humanities, the National Humanities Center, and the Folger Shakespeare Library. Each of these institutions offer concentrated study of topics across broad specialties and they often take place at universities with excellent research libraries. The courses can last from one week to five weeks and range broadly in topic. I have been fortunate to participate in a number of these seminars and institutes and my scholarship benefits from the engagement and contacts I have made through each experience. While these courses may not be an option for every scholar, they do offer another way to fund research and further careers for both full-time and part-time faculty. Before briefly describing my experiences and the benefits for teaching and scholarship, I must offer two caveats: 1 . To take advantage of these opportunities, scholars must keep at least a portion of their summer free from teaching, and 2. scholars must be willing and able to travel.

Every summer, the National Endowment for the Humanities offers seminars and institutes in a variety of topics, located around the country. The topics change every year and the amount of competition can vary depending on the topic. The stipend offered for each type of course is generous and allows for taking full advantage of the time spent. (The NEH does run seminars and institutes in other countries but they do not tend to be as cost effective.) These programs can run from 2-5 weeks, and those who have never attended are given first preference to have a place in the program. Having completed one seminar or institute, participants are typically asked to wait three years before taking another one. I have been fortunate to attend two of these NEH sponsored opportunities and they have led directly to the advancement of my scholarly agenda and my teaching.

The summer programs for college and university teachers are divided into seminars and institutes. Graduate students, adjunct faculty, and independent scholars are welcome to apply, and each of the programs I attended included a broad mix of scholars. The seminar is more focused on scholarship and functions beautifully as a chance to have access to an excellent library, the resources of an advanced scholar, and the time to pursue an independent project. In 2007, I participated in a seminar about the transatlantic slave trade at the University of Virginia 
organized by the prominent Africanist, Dr. Joseph Miller. This was a 6-week seminar of which the first four weeks involved intense discussions about aspects of the topic with visiting scholars in the morning and afternoons free to use the library. The last two weeks allowed for consultations with the seminar director as we worked on our projects. I used that time to develop a book proposal and a fellowship application. I received the fellowship in large part because I had an experienced researcher guiding me through the application process.

The NEH Institute is designed to provide an intensive orientation to a topic in order to develop innovative coursework on that topic. The amount of time allowed for independent research depends on the structure of the Institute, but scholars still have access to the library and resources of the university hosting the Institute. I had the luck to attend an Institute on Black Resistance in the Tropical Atlantic in summer 2011 at Johns Hopkins. That experience introduced me to some preeminent historians in the field of slavery studies. I also benefitted from a large and diverse group of scholars, many with whom I have maintained professional contact. Through that Institute, I learned of fellowship opportunities, publishing opportunities, and landed two speaking engagements based on my research. The additional value of the Institute related directly to my teaching. I have a wealth of material to use in the classroom and the stimulating discussions helped me to develop two new courses.

In the summer of 2008, I participated in a week-long course at the National Humanities Center in the Research Triangle Park of North Carolina.This summer course is geared very particularly towards junior scholars and can be highly competitive. I applied three times before I was accepted. Participants are provided with a stipend in addition to coverage for travel to and from the Research Triangle, housing, and books. The topic of the course was the study of Chaucer and was directed by Seth Lehrer. This topic, while outside my field of research, provided excellent material for my teaching and scholarly repertoire. In terms of teaching, the more common type of course taught by junior faculty involves some form of survey. At my teaching institution, where English is largely a service department, I rarely have the opportunity to teach a course that is focused on my field of research. Moreover, only two other faculty members (out of 24) specialize in literature prior to the nineteenth century. The value of the seminar quickly moved beyond the specialist material on Chaucer. The discussions that I had with this community of junior scholars from very different kinds of institutions allowed for valuable insight into the academic world. Many of us are trained at top institutions to succeed in jobs at competitive, research-oriented colleges and universities. However, acquiring those jobs can be a challenge. The community created out of just one week of intensive study prompted a fruitful exchange of information about teaching techniques, managing administrative responsibilities, and research at non-research oriented schools.

In terms of scholarship, the seminar broadened my understanding of literary studies and research. The majority of participants worked with either Middle English or Old English sourcesmaterials with which I have only a slight familiarity. I learned a great deal about research methodology when working with scanty or corrupted sources. In turn, I brought my understanding of print culture and the later repercussions of some our points of inquiry to the discussion. We all came to see our materials through fresh eyes and consider new forms of analysis. In addition, the NHC provided all participants with access to the excellent resources of research libraries as well as office space in which to study the materials. Though we did not have 
much opportunity for research in primary sources, the breadth of secondary materials kept each afternoon fully occupied. The additional benefit involved familiarity with the Center's facilities and the materials in the various libraries. The NHC offers a few highly competitive fellowships. Most fellowship committees want to see how the resources of their particular library, organization, or center would be necessary to an applicant's project. Having first-hand experience of the collections can only enhance the application.

Finally, the Folger Shakespeare Library offers innovative seminars on topics broadly connected with the Early Modern World. They invite important scholars who are conducting creative research to discuss new sources, new methodologies, and new ways of asking the research question. The value of such a seminar is the interdisciplinarity of the group of scholars who are assembled. They accept scholars at every stage of the degree and the career, which makes for a fascinating conversation about the materials. The single caveat is that only applicants from the consortium universities can apply for funding. However, if funding is a point of concern, the library staff are very helpful and willing to make every effort to assist in acquiring other sources of funding.

These experiences have critically shaped my scholarship and my teaching. The generous stipends have allowed me to travel to a number of important research libraries around the country and acquaint myself with their considerable resources. I am still in touch with many of the scholars that I met during the various seminars and we have discussed collaborative projects to pursue in the future. I also benefited from the advice and support of the senior scholars who directed these seminars. Finally, I have taught three new courses based on the materials that I studied and analyzed through my various courses. The opportunities for research, community-building, and developing innovative coursework are richer than may be imagined in this economically tightened environment.

National Endowment for the Humanities http://www.neh.gov/divisions/education/summerprograms

National Humanities Center http://nationalhumanitiescenter.org/summerstudy/index.htm Folger Shakespeare Library http://www.folger.edu/Content/Folger-Institute/Folger-Institute.cfm 